\title{
El dolor de sentirse pájaros y no poder cantar: las declamadoras en el universo poético de Alemany Villa
}

Fecha de recepción: 11/12/2019 Fecha de aceptación: 4/6/2020

\begin{abstract}
Resumen
A comienzos del siglo XX el teatro nacional atravesó un período de particular intensidad experimental como otros fenómenos estéticos del momento (la plástica, la música, la literatura, la cinematografía, la arquitectura). La escena comenzó a albergar nuevas experiencias estéticas que surgían del cruce entre la cultura letrada y el espectáculo. Entre ellas se encuentra el arte de la declamación. Este artículo se centra en la década de 1920, período en el cual esta disciplina experimenta un proceso de expansión y autonomización, abandonando así el claustro escolar para trasladarse a la escena teatral. Las secciones "Intérpretes poéticos" y "Por el mundo de la declamación" de la revista cultural Comoedia (1926-1933) permiten reconstruir el caso de la Escuela Argentina de Arte Universal, dirigida por Alemany Villa hacia mediados de la primera década del siglo XX, hasta su muerte en 1931. Las fotografías y reseñas críticas de las audiciones poéticas publicadas por la revista revelan las contradicciones en torno al proceso de autonomización de esta práctica estética. Se trata de fuentes que iluminan las tensiones entre dos órdenes de representación, el textual, propio de la cultura letrada; y el visual, con la conformación de una industria del espectáculo.
\end{abstract}

Dalabras clave: Poesía; declamación; Berta Singerman; performance; teatro.

\begin{abstract}
At the beginning of the 2oth century, the national theater went through a period of particular experimental intensity like other aesthetic phenomena of the moment (plastic, music, literature, cinematography, architecture). The scene began to harbor new aesthetic experiences that arose from the intersection between literary culture and entertainment. Among them is the art of declamation. This article focuses on
\end{abstract}


the 1920 s, a period in which this discipline undergoes a process of expansion and autonomization, thus leaving the school cloister to move to the theater scene. The sections "Intérpretes poéticos" and "Por el mundo de la declamación" of the cultural magazine Comoedia para todos (1926-1933) allow us to reconstruct the case of the Escuela Universal de Arte Universal, directed by Alemany Villa towards the middle of the first decade of the 20th century, until his death in 1931. The photographs and critical reviews of the poetic auditions published by the magazine reveal the contradictions surrounding the process of autonomizing this aesthetic practice. These are sources that illuminate the tensions between two orders of representation, the textual, typical of literary culture; and the visual, with the conformation of an entertainment industry.

Key Words: Poetry; declamation; Berta Singerman; performance; theatre.

Juan Lorenzo Alemany Villa (1877-1931) fue, ante todo, un visionario. En un siglo marcado por la primacía de la imagen como medio de representación y como signo de lo real, Villa, formado en el circo criollo de los Podestá y egresado de la bucólica academia de los payadores, ${ }^{1}$ inauguró en la primera década del siglo XX su "Escuela Argentina de Arte Universal". ${ }^{2}$ Es ahí donde enseñó a jóvenes de la sociedad "decente" - en su mayoría mujeres - y niñas y niños porteños, el arte de la declamación. La novedad de su propuesta educativa radicó en la materia espectacular con la que se propuso modelar a sus discípulas. Fue un pionero en reconocer el potencial artístico de una práctica legendaria, que había sido encerrada desde el siglo XIX en el claustro escolar. Esa es precisamente la novedad que aportó su empresa educativa a la escena pública.

A propósito del giro que prodigó Berta Singerman (1901-1998) en la praxis de la interpretación poética, Ana Porrúa apunta que el arte de la declamación había estado destinado a participar, junto con otras prácticas artísticas, del adoctrinamiento de la lengua de los inmigrantes: "A principio del siglo XX la declamación se creía política de estado (...) y pasó a ser el modo de comunicar la poesía y también de legitimarla" (Porrúa, 2011: 199). La escena pedagógica se sostenía en la obsesiva escucha de una voz higiénica, pulida, depurada de cualquier sonido extranjero.

En un momento de clara ebullición de diferentes consumos espectaculares masivos (teatro, cine, radio, magazine y revistas para todo público, como por ejemplo en la Argentina, El Hogar), Alemany Villa decidió hacer con su método de enseñanza un nuevo negocio en el mundo del espectáculo. Su Escuela anticipó la proyección espectacular que el arte del buen decir adquiriría a mediados de la década de 1920, antes incluso de que la declamación lograra institucionalizarse como un arte autónomo en la educación terciaria con la fundación del Conservatorio Nacional de Música y Declamación por parte de Carlos López Buchardo en 1924. En esta faceta del proceso de expansión de la práctica artística, una de las figuras fundamentales fue Alfonsina Storni, a través de su cátedra en el Conservatorio y la organización de recitales de poesía, especialmente el Primer Festival de la Poesía de Mar del Plata en 1926.

1 No contamos con datos precisos sobre la vida de Alemany Villa, los aspectos de su biografía mencionados fueron extraídos de lo publicado por él y otros escritores en los artículos sobre las audiciones poéticas de la Escuela Argentina de Arte Universal en la revista Comoedia.

2 En la revista nunca se especifica el año de inauguración de la Escuela, pero se hace alusión a los veinte años que lleva trabajando en su instituto y se establece una diferencia entre sus alumnas de la primera época y las nuevas, las que - como se verá- aparecen representadas en la sección "Intérpretes poéticos".

3 Nacida en Minsk, Rusia, Berta Singerman fue probablemente la más exitosa declamadora de su tiempo y también la principal promotora del arte de la declamación como espectáculo. En 1920, debutó en la película muda La vendedora de Harrods, de Francisco Defilippis Novoa. Su primera audición poética se produjo en 1921 y su última presentación pública la realizó en el Teatro Colón en 1990. 
En el caso de Alemany Villa, su método no solo se difundía en la Escuela, sino que contaba también con su propia empresa editorial, ${ }^{4}$ cuyos productos se diferenciaban de los tradicionales manuales de declamación en la medida en que ponían en segundo plano los métodos de enseñanza que buscaban pulir la voz, neutralizar el timbre y depurar el sonido de toda aspereza, para ofrecer un repertorio de poemas de diferentes y variadas corrientes poéticas en los que la intención del decir se centraba tanto en el significado de las palabras como en la "ilustración viviente" de las obras, poniendo el foco en el dominio del cuerpo y, concretamente, de la gestualidad. Afirmaba Villa:

Cuando leemos una poesía, si esta toca nuestra receptividad, de inmediato nos dedicamos a aprenderla de memoria. Ahora bien, lo primero que debemos hacer es averiguar el significado de esas palabras que no son de uso corriente en nuestras conversaciones. Ya en poder nuestro el significado de cada una de ellas, empaparnos del espíritu que anima a la poesía; ver las imágenes descriptas por el poeta, recordar cuadros, retratos, libros y todo cuanto pueda informarnos. (Villa, s/f: 9)

El método de Villa consistió en desplazar la producción de sentido de la voz a la gestualidad, del dominio de una sensorialidad y sensualidad sonora que expresa y apela, a otra dominada por la visualidad. Esta operación didáctica requería de un alto grado de racionalidad: "Lo fundamental en la interpretación poética es pues ver lo que se dice y saber por qué se dice y para ello es indispensable leer mucho, oír mucho, observar y estudiar mucho también" (Villa, , s/f: 12). El carácter emergente de este método se pone en evidencia ante la insistente necesidad de brindarle coordenadas interpretativas que lo vuelvan legible:

Como allí [se refiere a la Escuela] no se va a pasar el tiempo, como dicen algunos, ni allí se enseña solamente a recitar, como quieren otros, sino que se aprende a interpretar el pensamiento que encierran las poesías, los alumnos tienen que expresar las pasiones humanas, a saber: la admiración, la bondad, la ternura, el amor, el odio, la rabia, el asco, el desprecio, la vanidad, la perversidad, la avaricia, el despecho, el espanto, el entusiasmo, en fin todo lo que se relaciona con el ser humano; todo esto salpicado con referencias y anécdotas literarias o artísticas, de suyo instructivas (...) Y si a uno se le enseña que el espanto se expresa con la voz ronca, los ojos agrandados, los labios contraídos en un rictus y los dedos encorvados como garras, a otro no se le puede enseñar de otra manera sin desvirtuar el sentido del poema. (Villa Alemany, 1927: 41)

Villa creó un método artesanal que sacaba al arte de la declamación de la escuela para situarlo en el teatro y convertirlo en un espectáculo a través de las audiencias poéticas promovidas, en buena medida, por su institución.

Su método se apoyaba en dos elementos diferentes, que se volvían inteligibles en dos niveles de análisis distintos: por un lado, en términos discursivos; por otro, en términos materiales, vinculados con la circulación de ese nuevo entramado discursivo y de su retórica. En términos retóricos, su principal recurso para convertir la recitación en un verdadero arte escénico consistió en cambiar el eje de este arte de la musicalidad poética al gesto y la corporalidad de la pose. En cuanto a lo material, para la difusión de su método, contaba con un soporte específico: la revista de espectáculos Comoedia

4 Alemany Villa publicó bajo el sello Casa Editora A. y G. Casellas cuatro libros que contienen diferentes repertorios de poesías seleccionadas por él mismo: Chispazos de Sol, Cofre de Armonías, El Universo Poético, El libro de la risa y Yo pecador... (1926). Salvo por el caso de Yo pecador..., los otros tres libros no indican su año de edición; las sucesivas ediciones que aún hoy pueden rastrearse a la venta y en varias bibliotecas hablan de su éxito. Por fuera de este conjunto de publicaciones editadas por el sello A. y G. Casellas, se encuentra El libro de gloria (s/f, Editorial Ferrari). 
(1926-1933).5 Puntualmente, las secciones "Intérpretes poéticos" y "Por el mundo de la declamación" conformaron la gran estrategia comercial para promocionar su Escuela como el único espacio legítimo donde era posible aprender a representar el arte del buen decir.

De este modo, cualquier alumno que siguiera las enseñanzas que prodigaba el maestro tenía asegurada su aparición en una de las revistas de teatro más reconocidas del momento. ${ }^{6} \mathrm{Si}$ bien desconocemos los detalles del vínculo que mantuvo Villa con la revista, lo que se torna evidente es que se trató de una relación estrecha que, a través de los sucesivos números de Comoedia, se reveló como un pacto comercial exclusivo entre su Escuela y el espacio que la revista le reservó en las páginas a su promoción. En efecto, la alianza de Villa con Comoedia le permitió transformar a la revista en un verdadero escenario impreso en el cual sus alumnas desfilaban ante los ojos de otro público (no el más inmediato y previsible de la familia o la escuela) sino el público anónimo, dentro del cual habría, además, jóvenes deseosos de ser espectadores y probablemente ejecutores del arte de la declamación. Es decir, potenciales estudiantes que compraban la revista, reactivando la alianza económica entre redactores-publicistas y lectores-consumidores.

Como se indicó, dos de las secciones de Comoedia estuvieron particularmente dedicadas a la Escuela de Alemany Villa. Para comprender mejor cómo funcionó la puesta en escena de la tarea escolar y espectacular de Alemany Villa en la revista durante la década de 1920, examinaremos a continuación estas dos secciones, tanto en lo que hace a sus textos como a las imágenes - cuando las presentan-. Si bien el acceso a las secciones no es equivalente al acceso a las prácticas efectivas de la Escuela, consideramos que el análisis de esas representaciones puede darnos indicios del funcionamiento efectivo de tales prácticas y de las formas en que fueron percibidas e interpretadas en su tiempo.

\section{Las replicantes}

Cuando el 16 de marzo de 1927, en su $\mathrm{N}^{\circ}$ 21, la revista de espectáculos Comoedia comenzó a publicitar la Escuela Argentina de Arte Universal en la sección "Intérpretes poéticos", Villa, en la prosa hiperbólica que lo caracterizaba, describió el arte de la declamación como una suerte de necesaria unión entre la música, la escultura y la poesía:

Música de las ideas que es sonoridad agradable para el oído que las escucha. Música pero sin esfuerzo, sin ese sonsonete arbitrario y saporífero que algunos imprimen a la declamación. Música y no ese canto ampuloso y falso desvirtuador del concepto fundamental de toda poesía. Música, armonía, deleite, todo eso a base de verdad, de sinceridad, de honestidad artística y no de silencios empalagosos y poses ridículas, camelos al fin.

\footnotetext{
5 Comoedia fue una revista cultural del Anuario Teatral Argentino de publicación mensual que salió entre los años 1926 y 1933, y que contó con 86 números en formato magazine. Su costo en Capital Federal era de o,20 centavos y tenía distribución en Montevideo. La revista funcionaba como un acopio de reseñas, ensayos y notas gráficas de las diferentes prácticas artísticas (principalmente cine, teatro y radio) que formaban parte de la emergente industria del espectáculo en la ciudad de Buenos Aires. La imagen fue el principal medio con el que la revista se encargó de presentar al star-system local, tal como lo atestiguan sus tapas a color, donde generalmente se retrataba a los protagonistas de las obras teatrales estrenadas en los meses recientes.

6 Así lo demuestra el contenido de la revista, desde las entrevistas a grandes figuras de la cultura del espectáculo y la presentación de las diferentes compañías teatrales, hasta las publicidades de los dancings y teatros claves del circuito cultural porteño de la década de 1920.
} 
Escultura en la línea elegante del intérprete, en los ademanes bellos, en la euritmia y elasticidad de los gestos. Gracia en el andar, gracia en el movimiento de las manos, plasticidad en todo y por último pintura, pintura de tonalidades infinitas por medio de la voz, de los gestos, de los ademanes y de las miradas.

Pintura, relieve pleno del cuadro evocado por el autor del poema que ha de interpretarse y por sobre todo, comprensión total absoluta de lo que se dice, documentación fiel y escrupulosa minuciosidad en los matices de la voz, de los festejos, de los ademanes y de las miradas (...) La interpretación poética lo reúne todo, pero así como es bella e insuperable, se trueca fácilmente en algo detestable cuando un ser indigno la profana. (Villa Alemany, 1926: 61)

Si hay algo que en el arte de la interpretación pasa, para este modesto Prometeo, a segundo plano, es la voz. En efecto, la voz quedaba, desde su perspectiva, subsumida a la ominosa presencia del cuerpo en escena.

De acuerdo con Graciela Montaldo, en el cambio del siglo XIX al XX, el espectáculo se convirtió en el eje de la vida de las masas. La autora considera que entonces "[L] a cultura letrada se trama con el espectáculo popular generando nuevos vínculos sociales, prestando especial atención a espacios y agentes de transformación y a las intersecciones entre ambas prácticas" (Montaldo, 2016: 75). Siguiendo a Guy Debord, Montaldo afirma además que el espectáculo no debe ser considerado como un conjunto de imágenes sino como una relación social dinámica entre personas mediatizada a través de la imagen. Como en la emergencia de los nuevos sistemas de representación se verifica también "el triunfo de la visualidad frente a la textualidad" (ibídem: 78), tales vínculos operan particularmente a través de códigos, efectos y representaciones visuales.

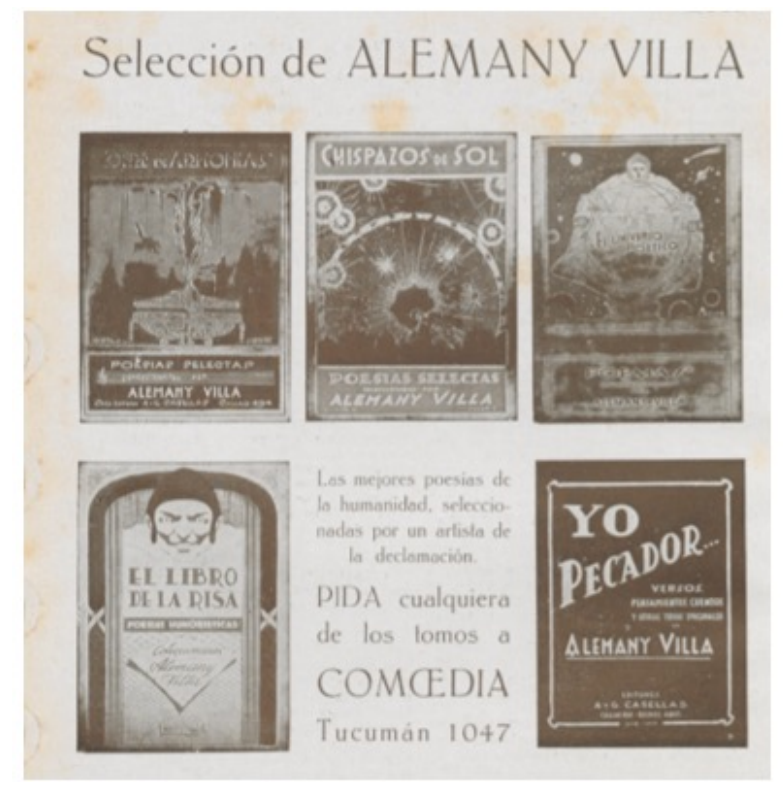

Publicidad de la colección de libros de Alemany Villa, Comoedia, № 21, 10 de marzo de 1927.

Si lo entendemos así, no sorprende que en los ensayos que Villa publicó y firmó con su nombre en Comoedia, no solo la voz quedara en segundo plano frente al cuerpo en escena, sino que las referencias que predominaban se dirigieran al mundo de la plástica, universo semántico que actuaría como hilo conductor de los artículos y notas gráficas de la revista sobre las audiciones poéticas que Villa organizó una vez al mes desde 1926 hasta 1931, el año de su muerte. 
Con solo recorrerla se advierte que la sección "Intérpretes poéticos" de Comoedia se ocupaba íntegramente de la Escuela Argentina de Arte Universal. La autora de esta sección era una recitadora de nombre - sea real o no- significativo como una consigna: Fidela Solari. Su escritura, que oscila entre un tono jocoso y punzante, presenta una suerte de informe de desempeño de las audiciones públicas que las alumnas de la escuela de Alemany Villa realizaban mensualmente. Hasta el número 36 ( $1^{\circ}$ de abril de 1928 ), cuando Fidela fue reemplazada por Ramiro de la Torre, la presentación de las declamadoras estaba acompañada por el retrato fotográfico de cada una. Cuando De la Torre asumió la redacción de la sección, las fotografías desaparecieron y las únicas imágenes serían verbales; es decir, aquellas evocadas por la escritura. ${ }^{8}$

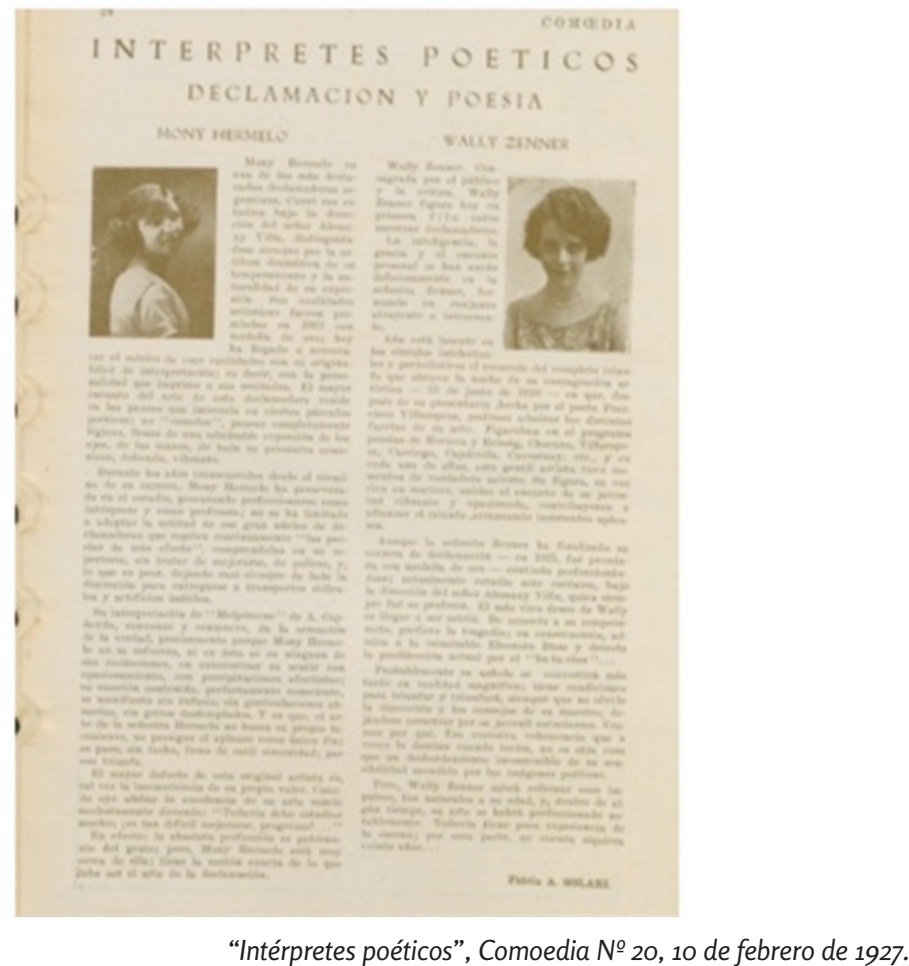

Resulta interesante detenerse sucesivamente en las dos versiones que construyeron Solari y de la Torre en la redacción de esta sección; entre otras cuestiones porque, como se ha mencionado, esa sección de la revista resultó la gran estrategia comercial de Villa. Pero además, y en términos más generales, porque la sección completa puede pensarse desde la categoría de "dispositivo", tal como la formula Giorgio Agamben. En "Qué es un dispositivo" - ensayo donde se propone ajustar el alcance metodológico de ese concepto foucaultiano-Agamben presenta varias definiciones de este concepto, entre las cuales una nos interesa particularmente para pensar esta sección: "El término dispositivo nombra aquello en lo cual y a través de lo cual se realiza una actividad pura de gobierno sin fundamento en el ser. Por esta razón, los dispositivos siempre deben implicar un proceso de subjetivación, es decir, deben producir su sujeto" (Agamben, 2016: 18). Si un dispositivo es aquello que tiene la capacidad de capturar,

7 Fidela Solari se presentó en el $N^{\circ} 19$ (16 de enero de 1927) de Comoedia con una fotografía suya y su monólogo de los celos "Consejos a una rival" (dedicado a los alumnos de la Escuela Argentina de Arte Universal). El segundo redactor de la sección, Ramiro de la Torre, irrumpió un año más tarde y desplazó a Fidela de la autoría de la columna sin una presentación oficial (y sin que tampoco puedan consignarse más datos sobre su existencia real o meramente enunciativa).

$8 \mathrm{El}$ repertorio de las audiciones aparece de manera intermitente e incompleta en las secciones dedicadas a la Escuela Argentina de Arte Universal. Generalmente, en las reseñas de las audiciones aparecen consignados de manera parcial algunos de los títulos recitados por las declamadoras. 
orientar, determinar, modelar y asegurar los gestos, las conductas y los discursos de los seres vivientes, las reseñas sobre las declamadoras publicadas en Comoedia pueden considerarse una forma del control inscripta en la gráfica de la revista donde aquello que se busca - en el proceso de construcción espectacular de la práctica de la declamación- es retener y orientar constantemente a las declamadoras hacia su posición subjetiva de alumnas.

En la generación de los perfiles de las declamadoras, el lector de la revista debe tener en claro que cualquier recitación que se corra de las precisas indicaciones realizadas por el maestro y aventure una suerte de osadía interpretativa - lo que la prosa de Comoedia calificaría como "un camelo"-debe ser excusada, ante todo, por la juventud de las declamadoras y por su falta de estudio. Tal reparo exige una clasificación previa, que puede encontrarse en una de las notas "teóricas" o ensayísticas escritas por Villa -que complementan la sección inaugurada por Fidela-. Allí el gran maestro distingue dos tipos de alumnas: aquellas que nacen con el don de la interpretación y cuya supervisión no requiere de una atención morosa; y otro conjunto, el más amplio, que debe seguir atentamente las clases e indicaciones del maestro artista:

Hay dos clases de alumnos: los que con una pequeña ayuda llegan a ser algo porque sí, porque tienen condiciones naturales (intuición, genio, suerte, ángel, como quiera llamársele) y los que también llegan a ser algo, aunque de distinto modo; es decir, a fuerza de constancia y aplicación y, sobre todo, gracias a la buena dirección que tuvieron desde sus comienzos. A estos últimos me refiero especialmente; ellos son los que casi siempre, después de haber recibido unos cuantos aplausos (que más bien se les otorgan como estímulo que por derecho) ya se creen maravillas y en lugar de perseverar se amaneran y atrasan al pretender "manejarse" solos. Esos alumnos deberían ser consecuentes en el estudio y no olvidar que si hasta "los otros" necesitaban muchas veces una sabia dirección que corrija sus defectos con más razón necesitarán siempre ellos esa dirección para llegar a triunfar ampliamente. (Villa, 1928: 22)

Un ejemplo más concreto de esta formulación puede encontrarse en las caracterizaciones que todos los meses llevaba a cabo Fidela. Por caso, en la presentación en sociedad de dos jóvenes, llamadas Mony Hermelo y Rosario Beltrán Nuñez. De la primera dice que:

El mayor encanto de esta declamadora reside en las pausas que intercala en ciertos párrafos poéticos. No "camelos", 9 pausas completamente lógicas, llenas de una admirable expresión de los ojos, de las manos, de toda su personita armoniosa, delicada y vibrante (...) Su interpretación da la sensación de verdad porque no se esfuerza, ni en esta ni en ninguna de sus recitaciones, en exteriorizar su sentir con apasionamiento, con precipitaciones efectistas; su emoción contenida, perfectamente consciente, se manifiesta sin énfasis, sin gesticulaciones absurdas, sin gritos destemplados. (Solari, 1927: 24)

En cuanto a Rosario Beltrán Núñez:

9 La expresión "camelos" aparece con frecuencia en las reseñas sobre las interpretaciones poéticas realizadas por las declamadoras. El sitio especializado www.solotango.com define este término así: "camelo" (рор.) Apariencia, exhibicionismo// engaño, farsa, mentira, cuento, trampa// galanteo, requiebro// conversación engañosa, exceso de palabras." (http://www.todotango.com/comunidad/ lunfardo/termino.aspx? $p=$ camelo [consultado el o8/03/2019]). Vale notar dos cuestiones diferentes: la primera, el carácter coloquial y popular del término elegido para denunciar el engaño en el arte del decir; el segundo, el rasgo específicamente verbal del tipo de engaño que supone el "camelo". De algún modo el carácter reiterado de este término puesto en juego en la sección demuestra que las alumnas solían salirse del método instalado por Villa para acercarse a otro tipo de modalidad interpretativa, más cercana seguramente a la desarrollada por Berta Singerman en esa época. 
A su temperamento dramático la señorita une una voz vibrante y bella, que traduce sin dificultad los distintos matices de la poesía. Desde hace algún tiempo, esta joven artista cultiva también con entusiasmo el estudio de las letras, lo cual añade un mérito más a los ya citados, pues su preparación literaria y crítica da mayor amplitud a sus condiciones de intérprete. (Solari, 1927: 12)

En esta línea también están los elogios al niño Ismael Alchournón, quien había ingresado a la Escuela a los cinco años y al momento de la audición publicada contaba con doce. Sobre Ismael Alchournón, Fidela Solari consideraba que:

Es un poco gordito para encarar papeles de galán, pero el ejercicio y la dieta, aunque duros, en estos casos son sumamente eficaces. Este inteligente declamador, premiado en ocasión con medalla de oro, debe preservar y continuar perfeccionándose; se encuentra en las mejores condiciones para ello puesto que ya el estudio le ha hecho conocer los resortes que embellecen el arte y la práctica le permite dominar con criterio exacto sus aptitudes naturales. ¡Lamentable sería que tan bella promesa se malograra por desidia o falso convencimiento del propio valer! Porque aunque exista talento en una determinada personalidad la juventud excesiva necesita dirección. (Solari, 1927: 12)

El carácter reiterado que toma en la sección la cuestión del estudio se mantendrá a lo largo de todos los números. La necesidad de permanecer en la órbita de la Escuela para convertirse en verdaderas artistas tomó una dirección más drástica cuando Fidela Solari dejó de estar a cargo de la sección y, en su lugar, sin mediar una presentación, apareció Ramiro de la Torre, quien desplegaría una escritura mucho más enfática acerca de la cuestión pedagógica. Dos novedades surgieron de este cambio. La primera, que la sección siempre suspicaz respecto de la falta de estudio y perseverancia de las declamadoras, en la escritura de De la Torre se volvió plenamente paranoica; y en segundo lugar, el hecho de que las presentaciones ya no contenían imágenes.

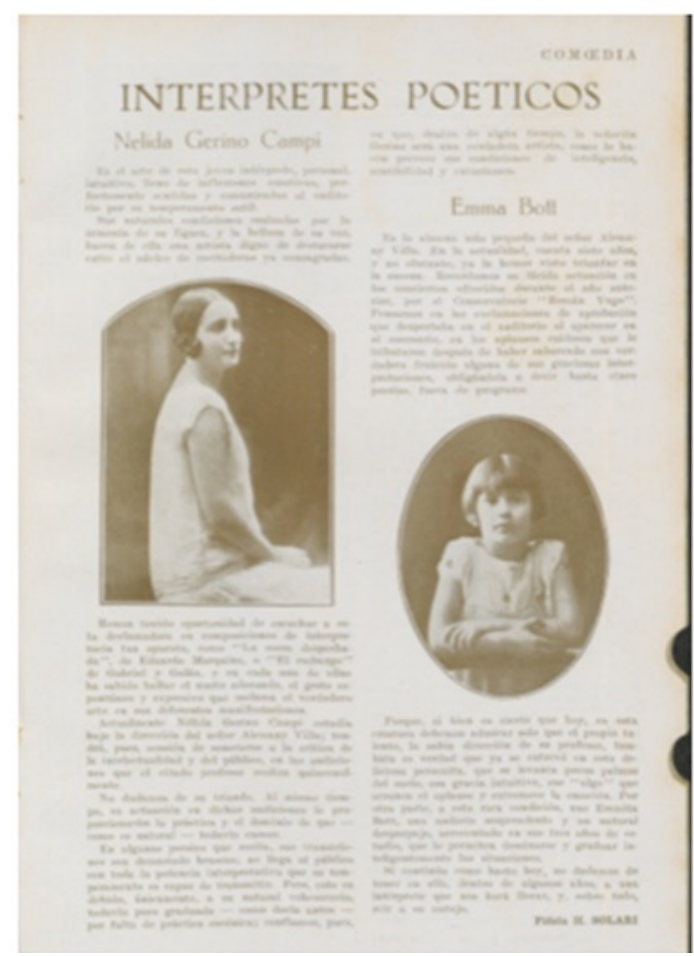

“Intérpretes poéticos”, Comoedia №24, 10 de mayo de 1927. 
Las fotografías de la sección funcionaron siempre como un límite imaginario debido a que las imágenes, tomadas en estudio, mostraban a las declamadoras en escenarios ajenos a las audiciones, en poses necesariamente estáticas, mudas. En esta sección los signos que pueden leerse en las imágenes se vuelven de algún modo redundantes respecto de los informes que realizaba Fidela Solari. Las poses que en las fotografías asumían las declamadoras nos devuelven una imagen neutra que se ajusta a la descripción de su rol de estudiantes aplicadas. En este sentido, la sección "Intérpretes poéticos" sujetaba las imágenes a la escritura y anulaba la multiplicidad de sentidos que de ellas podrían desprenderse. El mensaje icónico quedaba subsumido al mensaje lingüístico: los retratos de las declamadoras no pueden ser leídos sino como una suerte de anuario escolar.

Por lo tanto, siguiendo a Barthes (1986), la escritura de Fidela Solari tenía una función de "anclaje" respecto de la imagen: clausuraba otros posibles significados para anudar esos retratos a su único lugar de pertenencia, la Escuela Argentina de Arte Universal, donde las declamadoras interpretaban poesías en su rol de alumnas, sin que el lector de la revista pudiera sustraer de esas imágenes otros signos ni realizar otras interrogaciones sobre los posibles vínculos de esas fotografías respecto del resto de las imágenes de artistas que circulaban ampliamente por las páginas de Comoedia. Las fotografías, de este modo, anclan su significado en la caracterización de las presentaciones desarrolladas en la escritura, afirmando el dispositivo de control, cuya función consistía en visibilizar y orientar convenientemente a los lectores de la revista.

En ese nuevo escenario de papel, la mirada tutelar de Fidela expresada en su escritura subordinaba a su carácter de alumnas aplicadas todo tipo de singularidad, convirtiéndolas en meras replicantes. Las declamadoras emergían de su palabra como frágiles ninfas de porcelana, pájaros que todavía no habían alcanzado la madurez necesaria para migrar y tener una voz propia, una suerte de bestiario enjaulado que debía preservarlas de convertirse en verdaderas bestias. Para enfatizar esta tarea de cuidado, se agigantaban los peligros que las rodeaban, entre los que se encontraban los otros guías artísticos, los falsos apóstoles del arte lírico, quienes engañaban en sus clases a las alumnas asegurándoles rápidamente una cualidad artística que no existía, malogrando así sus aptitudes líricas por falta de una verdadera disciplina en el arte de la declamación:

La futura víctima, dominada por la nerviosidad peculiar de aquella persona que va a dejarse oír, con objeto de recoger la impresión de lo que ella conceptúa un gran "professore", se pone en contacto con uno de esos mercaderes del arte y previa confesión de propósitos inicia a pedido de este una corta vocalización. El activo comerciante de gargantas, fingiendo un gran entusiasmo, interrumpe de pronto aquel "análisis" y en una pose grotesca o llevando a cabo movimientos de clown se declara un panegirista de gran estilo. (Martini, 1927: 8)

En todo caso, las aspirantes declamadoras debían dirigirse a los verdaderos maestros para que "los jóvenes, adornados excelsamente por Natura, no lloren más tarde el destronamiento fatal de sus esperanzas y el dolor de sentirse pájaros y no poder cantar" (Martini, 1927:8). Otro de los peligros, que siempre estaba al acecho de estas pequeñas y tenues estrellas era precisamente la presencia de Berta Singerman, quien en 1926 acababa de volver de la gira que había realizado por Europa. Singerman era un modelo exitoso de declamadora emancipada: circulaba sola, sin maestro, con su propio método a cuestas, perfeccionado e importado quizás de su gira europea. Su originalidad llegaba al punto de cruzarse con uno de los grandes vanguardistas del 
momento: durante esa gira, justamente, mantuvo un diálogo asiduo con el gran poeta del futurismo italiano, Filippo Tommaso Marinetti. ${ }^{10}$

En la segunda etapa de la sección "Intérpretes poéticos", cuando De la Torre asumió su autoría, la sección comenzó a reducirse: perdió no solo las fotografías, sino también el espacio a página completa del que anteriormente había gozado para pasar a ser, paulatinamente, una suerte de apostilla insignificante, una intervención poco notable entre los demás contenidos relativos a espectáculos que la revista promocionaba. Con una salvedad significativa: que esa reducción registró desesperadamente un movimiento análogo de pérdida en el mundo referencial, la retirada de las alumnas de la Escuela Argentina de Arte Universal.

\section{Por el mundo de la declamación}

Siguiendo a Deleuze, Agamben observa en la tecnología del primer cine un espacio emergente donde los seres vivientes recuperan aquello que la vida burguesa había invisibilizado en su cuerpo: el gesto. De este modo, si hacia fines del siglo XIX la burguesía occidental había invisibilizado sus gestos más cotidianos: "En el cine, una sociedad que ha perdido sus gestos trata de reapropiarse de lo que ha perdido y al mismo tiempo registra esa pérdida (...) Para unos hombres a los que se les ha sustraído toda naturaleza, cada gesto se convierte en destino" (Agamben, 2001: 50).

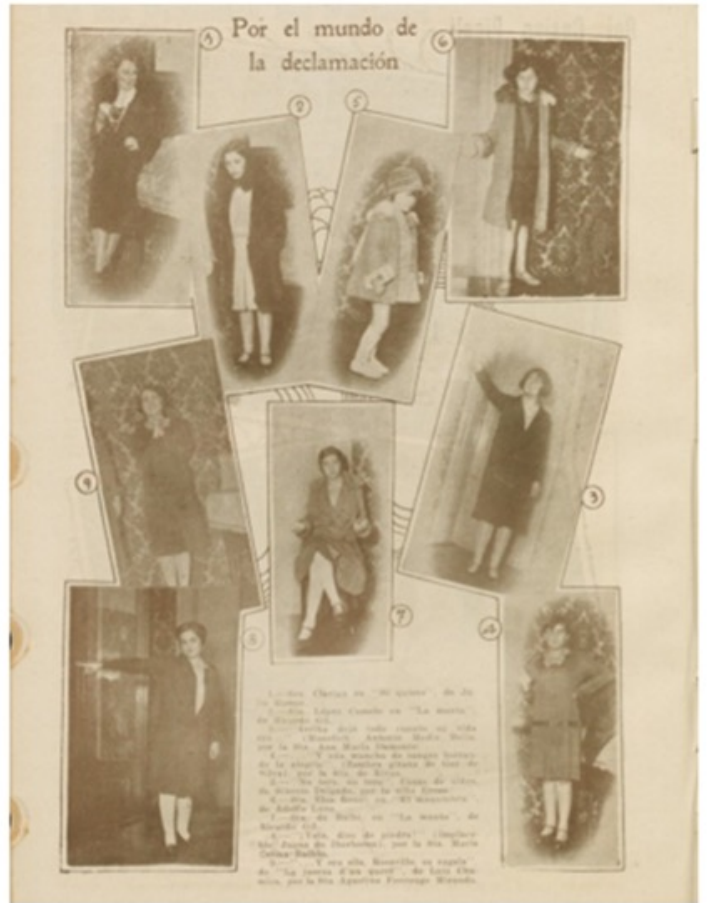

"Por el mundo de la declamación", Comoedia №29, 1ํ de setiembre de 1927.

\footnotetext{
10 La referencia a esta conversación se encuentra en el artículo "Berta Singerman y la declamación coral. Ideas viejas y disparates nuevos" en Comoedia. Allí se cita un fragmento de una entrevista dada por Singerman sin especificar su fuente: "En el año 1921, encontrándome en Italia y frecuentando con cierta asiduidad la casa de Arte de Bragaglia, en Roma, propuse al hoy conocido propulsor del arte experimental, la organización de unas funciones a base de recitación coral. Bragaglia, entusiasmado por la idea, que pareció nueva y original, me presentó a F. T. Marinetti y con este discutimos largamente el proyecto, estudiando la mejor forma de actuarlo" (№ 54, 1/10/1929, p. 17).
} 
En la medida en que el dispositivo de la sección "Intérpretes poéticos" había vaciado a las declamadoras de toda singularidad, otra sección, "Por el mundo de la declamación", dispuesta hacia el final de la revista y de intermitente aparición, les devolvió un espacio en el que aparecía la naturaleza viviente, aquello que la mirada de Fidela y De la Torre y los ensayos teóricos de Villa habían obturado.

"Por el mundo de la declamación" se inauguró en el N ${ }^{\circ} 29$ de Comoedia $(1 \% 12 / 1927)$ y su última entrega se realizó en el $\mathrm{N}^{\circ} 44(1 \%$ 12/1928). En esta sección, las declamadoras aparecían retratadas de cuerpo entero y la composición de las imágenes remitía a las secciones de la revista donde las compañías teatrales presentaban a sus elencos. A su vez, al contrario de "Intérpretes poéticos", en la sección "Por el mundo de la declamación" se encuentran imágenes donde las declamadoras aparecían retratadas en el espacio donde se habían desarrollado las audiciones poéticas. En esas fotografías, sus poses, lejos de ser estáticas y mudas, mostraban a las alumnas representando el acto de la declamación.

Los textos que acompañan a las fotografías funcionan como un pie de imagen que remite a los diferentes poemas declamados. Liberadas entonces de las ataduras que la escritura de Fidela Solari ejercía sobre sus retratos, estas imágenes alojan gestos que, capturados por la cámara que registraba las audiciones poéticas, condensan la acción dramática que contienen las poesías y reproducen imaginariamente el tono de los poemas. Si el gesto es el movimiento en el que "potencia y acto, naturaleza y artificio, contingencia y necesidad se hacen indiscernibles" (Agamben, 2001: 50), consideramos que el gesto plasmado en las imágenes de "Por el mundo de la declamación" les devuelve a las declamadoras una imagen que las libera de su posición subjetiva de eternas alumnas para acercarlas al de artistas de la escena y mostrarlas en su interpretación singular. Podría pensarse que tal despliegue gestual - donde las declamadoras representan los poemas que aparecen consignados al pie de las imágenes - posiblemente haya sido influenciado por la técnica actoral empleada en esos años en el cine silente, donde la pose es crucial para narrar y expresar. ${ }^{11}$ Precisamente porque consideramos que en el gesto se condensa la acción poética correspondiente a los poemas declamados es que esas imágenes iluminan a las declamadoras en su papel de verdaderas estrellas - y ya no de eternas replicantesal reponerles el movimiento que los retratos fotográficos y la escritura de la sección "Intérpretes poéticos" sustraía de sus actuaciones.

Es en las imágenes de "Por el mundo de la declamación" donde las declamadoras se alejan de su prescripción de alumnas y aparecen representadas en su cualidad de performers. Entiendo este término, en palabras de Pavis, no como el que define a un actor que interpreta un papel, sino a quien puede ser sucesivamente "un recitador, un pintor, un bailarín, y a causa de la insistencia puesta en su presencia física, un autobiógrafo escénico que establece una relación directa con los objetos y la situación de enunciación" (Pavis, 2008: 333).

Si algo se pone en evidencia en las páginas de Comoedia es la identidad huidiza de las declamadoras en tanto tales. Porque al fin y al cabo, ¿qué son? No pueden ser consideradas actrices, porque si bien comparten el despliegue de su declamación en un escenario, las recitadoras, por su formación, son incapaces de actuar. Y si lo hacen, hasta podrían perjudicar el arte teatral. Al menos, así lo asegura el profesor Gregorio Segovia en su nota "¿Sirve la declamación para el teatro?”. Esta conclusión

11 Como puede verse en el Anexo, la dirección que marca la mano de la Srta. María Celina Balbín (Figura 1) evoca el verso (mal citado, en el original es "dios de hierro") del poema "Implacable" de Juana de Ibarbourou. Otra estrategia de representación se encuentra en la manera en que las manos de la Srta. Balbín (Figura 2) reproducen el gesto de sostener la manta sobre la que versa el poema recitado: "La manta" de Ricardo Gil. 
es sostenida por una serie de "elementos de juicio" basados en la experiencia empírica de observar a las declamadoras realizando papeles en obras teatrales. Uno de los argumentos más terminantes consiste en el carácter solipsista del recitado que se diferencia del de la actuación, entre otras cosas, debido a que este está inmerso en un sistema de personajes que conviven en escena:

Digamos también que del teatro se ha desterrado el monólogo por considerarse poco teatral, poco natural como expresión del desarrollo de la vida. En realidad, el teatro no es sino una representación de un suceso de la vida, verosímil o verídico, en donde una de las cuatro paredes que encierra la acción se ha hecho transparente y permite ver al público lo que allí sucede. El monólogo no se concibe que exista, sino con mucho esfuerzo, en cualquiera de sus personajes. El declamador es un monologuista, en realidad y esto no es teatro. El declamador que pasa a actor cae en el vicio de "monologar" sus papeles, cuidando la ampulosidad del tono, el efecto de cuando habla y no de cuando escucha, cuidando su personaje sin cuidar el de sus compañeros, no por egoísmo sino porque no está al tanto de cómo debe hacerlo. Y así resulta deslucida la actuación de un actor que habla a un personaje que no sabe escucharlo. (Segovia, 1928: 42)

Si bien los "elementos de juicio" que desarrolla Segovia dejan muy en claro la razón por la cual está terminantemente prohibido confundir las dos prácticas artísticas -la declamación, al contrario del teatro, tiene un fuerte componente artificioso y por lo tanto visiblemente exagerado o "falso"-, no terminan de definir positivamente la práctica del arte del decir. Tampoco ninguno de los ensayos que scribió Villa ni sus secuaces tendrá por objeto definir de manera taxativa esta práctica liminar de la que solo sabemos que, en la línea de la Escuela Argentina de Arte Universal, tiene por propósito develar e iluminar en la puesta en escena, a través de la "correcta interpretación" de los versos, aquello que permanece oculto incluso para el autor de los poemas.

Este es el método que empleó y enseñó Villa en su escuela. Y si fue en el método donde radicó su singularidad - su originalidad - fue por ello que le resultó tan catastrófica la repentina y precipitada deserción de sus alumnas, quienes comenzaron a ausentarse de su escuela para lanzarse a realizar audiciones independientes y convertirse también ellas en maestras de la recitación. Esta ausencia tomó la forma de lista negra en la escritura de De la Torre. En este sentido, decía sobre Ada Lía Meza Virasoro:

Qué doloroso debe ser para un maestro ver, después de varios años de intensa labor, que por circunstancias inexplicables, todo aquel trabajo paciente y metódico se pierde, como el sol cuando se oculta tras la montaña y deja en las almas la tristeza de la noche que avanza, que para el espíritu no es más que el olvido que se insinúa. Si las alumnas egresadas recapacitaran un algo, sobre lo que decimos, nuestra cultura artística sería aún más luminosa, desde que ellas son las llamadas a irradiar esa luz recogida en un ambiente propicio. (De lal Torre, 1928: 68)

En todo caso, si las declamadoras de Alemany Villa, tal como las refleja la sección "Por el mundo de la declamación", no son ni pueden ser actrices, sí pueden ser performers. Esta categoría, lejana de su imaginario y del de la revista, nos permite hoy, sin embargo, subrayar algunos rasgos de su particularidad. Por un lado, su negatividad: son eso que no puede ser ni libre creación ni actuación. Por otro, la revista les devolvía al mismo tiempo otra imagen: la de la expresividad de su práctica, que las subjetivaría. En ese juego se abría un punto de fuga de su propia tarea, una posibilidad de relación "directa con los objetos y la situación de enunciación", como dice Pavis, que en las páginas de Comoedia parece posible. Y desde allí, desde esas imágenes, es que se abre otra fuga, esta vez literal: las recitadoras empezaban a abandonar la Escuela. 
Estas deserciones, comenzaron a asumir en la revista un carácter espectral. Así, por ejemplo, apareció Angélica Paz, de quien se decía que:

Es una de las más bien dotadas alumnas de la primera época de Alemany Villa. Exquisita sensibilidad, gusto delicado y discernimiento ponderable. A la par que su entusiasmo marchaban sus progresos artísticos, y era muy grande su entusiasmo. Y así fue que en poco tiempo adquirió un justo y valioso prestigio, tanto en sus audiciones personales, como en los festivales benéficos en que interviniera. La hemos escuchado en diversas oportunidades y aún perdura la agradable impresión recibida. Como muchos de sus condiscípulos, un silencio inexplicable la envuelve y la aleja y la borra... y es lástima. Esto último puede aplicarse a muchos otros de sus condiscípulos como ser: Martha Rodríguez Achával, Mony Hermelo, María Elena Snehiber, Eilia Cattáneo, Paulina Kirsbaunn, Ada Lía Meza Virasoro, César Manuel Berolotti, Lolita Mirales Escudero, Angélica Villanueva, Agustina Fonrrouge Miranda, Pepito Morillo, Nélida Bolluni, Rosario Beltrán Núñez, Maria Delia Soria, Ana María Damonte, y otros muchos olvidados, todos ellos poseedores de excelentes condiciones que después de una lucida actuación al lado de Alemany Villa, abandonaron el estudio o emprendieron otros derroteros, los que no siempre los han llevado a feliz puerto. Casi todos estos nombres han sido citados ya en Comoedia, y en adelante citaremos a los que aún no hemos nombrado. (De la Torre, 1928: 59)

Lo que aparecía entonces era la figura de la "plaga", personificada en la persona de Berta Singerman, el astro al que parecía que todas querían imitar. Porque el gran tormento de Villa consistió en la falta de reconocimiento que percibía por parte de sus alumnas desertoras, quienes en su rol de profesoras, al parecer, reproducían el método del maestro ocultando su "marca de fábrica". La deserción debió situarse en el proceso de expansión que la práctica artística experimentó en la década de 1920. En este sentido, la fundación de nuevas instituciones vinculadas con la disciplina, como el caso del Conservatorio, no solo estimuló desde el plano institucional la formación de esta "plaga" sino que delineó un problema que se silenció en las páginas de la revista: la competencia.

En todo caso, en esta producción en serie de declamadoras, la pregunta que aparece en el caso de las alumnas de la Escuela es la de la singularidad: si Alemany Villa era el portador original de la técnica, ¿dónde radicaba la singularidad de las declamadoras? ¿En qué consistía su originalidad de intérpretes? ¿Cómo se lograba consolidar un nombre propio en el universo poético del arte del decir?

\section{Un caso de mistificación}

La desaparición de las declamadoras de la Escuela Argentina de Arte Universal fue directamente proporcional a la construcción sacrificial que la revista realizara de la figura de Alemany Villa. A esto se sumó la representación, también por parte de la revista, de un campo cultural infectado por la epidemia de "atorrantes del idioma". Quien en un principio era meramente un maestro, con el correr de los números pasó a ser calificado como una suerte de sacerdote, el único, el original, que venía a impartir entre los mortales el exorcismo a la "plaga de declamadoras" que había invadido la ciudad. La necesidad de "higienizar el ambiente artístico" se convirtió en el dogma que impartiría el mismo Villa en los diversos ensayos que escribió para la revista. La retórica naturalista comenzó a impregnar las páginas dedicadas a la Escuela. En la entrevista "Cinco minutos con Alemany Villa", cuyo título sugerente denota el carácter ocupado de este maestro, el reporteado apuntaba: 
Ya ve Vd. cómo se desarrolla mi labor: desde el comienzo el estudiante se ve precisado a contemplar el recitado como espectáculo. Y se va templando frente a un público. Se opera un proceso natural de selección. El alumno que no tiene condiciones, se elimina por sí mismo, al notarse incapaz (...) Hace más de 20 años que lucho y estoy satisfecho. Mis discípulos me han dado muchas alegrías. Seguramente algunos han desvirtuado mi escuela, o mejor dicho su misma modalidad: los que me conocen, no me lo imputan. En más de mil audiciones he logrado generalizar un concepto, una emoción, una personalidad. Lástima que no siempre el alumno que se aleja mantenga conmigo vínculos tales que me permitan asesorarle. (Villa Alemany, 1929: 15)

La epidemia tuvo su causa precisamente en aquellas alumnas desertoras que se unieron a los nuevos aficionados de la recitación conformando un colectivo caracterizado como un conjunto de "desvergonzados que se atreven a presentarse en público sin la preparación necesaria" (Villa Alemany, 1928: 57). En todo caso, lo que se volvió evidente fue que, hacia fines de la década del veinte, la declamación había logrado desprenderse de sus ataduras escolares para convertirse en una verdadera experiencia estética espectacular, un bien cultural que gozaba de sus propios espacios de circulación y legitimación, pero al que todavía, como ponían en evidencia los artículos destinados a esta práctica artística, se quería domar y reconducir al claustro escolar. Probablemente el origen de todos los males fuera - una vez más- Berta Singerman, quien en Comoedia aparecía juzgada por el profesor de literatura de un colegio nacional, Suárez Bustamante, por sus interpretaciones:

La mayor responsable de esto es sin duda la Singermann [sic] quien, industrializando el recitado y consiguiendo un exagerado interés de la prensa por sus espectáculos, ha resultado un verdadero señuelo para incautos, sin contar que ella misma ha desnaturalizado la verdadera poesía, que por la forma en que la recita, estoy convencido no alcanza a comprender ni en mínima parte. He comprobado que todos los defectos que Comoedia apunta y que prestigiosos críticos imparciales del país y del extranjero hacen notar existen realmente en el recitado de la Singerman. Pero me parece que ustedes no insisten lo suficiente en dos cosas, a mi modo de ver capitales. Antes que nada, la impropiedad de casi todo el repertorio de la Singerman para la recitación y en segundo lugar su incomprensión garrafal que la lleva a cambiar palabras y frases enteras del texto original, que la induce a tonos equivocados en muchísimos pasajes de lo que recita, y que la obliga a subrayar con el gesto contrario el pensamiento de un poeta (...) Si no se ataja a tiempo el aluvión de recitadores y declamadoras que empiezan a afligirnos como una plaga nacional llegará el día en que los poetas se negarán a escribir un solo verso para no ver el fruto de su espíritu deformado, vejado y envilecido sea por profesionales sin escrúpulos, sea por niñas cursis sin responsabilidad. Prosigan ustedes su campaña de depuración y enseñanza; todos los que aman de verdad la íntima belleza de la poesía, todos los que tienen horror a la profanación del alma humana están en Comoedia. Está de más agradecer la adhesión. (D'Artagnan, 1930: 44)

La acusación que se le adjudicaba a Singerman, aquella de ser la artista que "industrializa" el recitado, resultaba alarmante debido a que visibilizaba el problema que tanto agobiaba a Villa: el de la producción artesanal del arte de la recitación, atada a la letra y a su interpretación literal, contra una interpretación liberada de la palabra.

En todo caso, si la presencia de Singerman resultaba tan disruptiva, esto se debía a que en su construcción de artista, esta performer conjugaba espectáculo y vanguardia. Su originalidad radicaba precisamente en la novedad que brindaban sus performances donde la artista parecía deshacerse de las ataduras que la palabra opera sobre el 
cuerpo para generar representaciones donde su interpretación tornaba singular aquello que en Villa era considerado, para el caso de sus alumnas, la reproducción de un método con la imprescindible mediación del maestro. Porque como pudo observarse, en las declamadoras de la Escuela, el gesto alojado en las imágenes de "Por el mundo de la declamación" era, a pesar de Villa, el síntoma de una singularidad que la escritura intentaba constantemente erradicar y borrar, pero que aún así permanecía en su inquietante afirmación.

\section{Mutis por el foro}

En la mañana de estío, toda vestida de oro como para una fiesta, una voz a la que ahuecaba la tristeza, nos alargó su desesperanza en las palabras de esta evidencia sin posible rectificación: Alemany Villa acaba de morir...

Comoedia, $\mathrm{N}^{\circ}$ 71, 1 de marzo de 1931.

Alemany Villa murió en febrero de 1931, en el transcurso de la desesperada campaña emprendida desde Comoedia contra toda forma espontánea de organización para el arte de la declamación. Su figura fue central en el despliegue del arte de la recitación a nivel local y, a su vez, su método buscó producir una estrategia comercial así como el montaje de un espectáculo. Para ello, creó una empresa que incluía su Escuela, sus libros, sus intervenciones y las de un equipo de enunciadores reales o inventados en Comoedia. En el anuncio de su muerte la revista se encargó de fijar su recuerdo como el del maestro artista que logró inaugurar una nueva experiencia estética. En adelante, el arte de la recitación pasaría en la revista a un segundo plano y en su lugar aparecería el cine sonoro como el nuevo espectáculo.

El registro de las audiciones que realizó Comoedia en sus páginas resulta interesante para evaluar el alcance que supo mantener, hacia fines de la década del veinte, el arte de la recitación como una práctica artística escindida de los espacios escolares formales y más básicos, donde acostumbraba circular. El regreso de Berta Singerman de su gira europea y los nuevos repertorios que traía también condujeron a la reflexión sobre las diversas modalidades expositivas que convivían en ese tiempo para esta emergente práctica espectacular.

Podemos concluir que el éxito del método Alemany Villa significó también su fracaso. Según se verifica en las páginas de Comoedia, la reproductibilidad del método generó el desgrane de la Escuela, así como la producción en serie y masiva de declamadoras produjo su definitiva autonomización. En todo caso, el gran fantasma fue Berta Singerman, una figura todavía a la espera de un estudio detallado de su trayectoria cultural, y cuyo interés, consideramos, radica en buena medida en que debe ser entendida como un producto de los cruces que se generaron entre la cultura de masas y la vanguardia en el ámbito del espectáculo de los años veinte.. 


\section{Q Bibliografía}

》Agamben, G. (2001). Notas sobre el gesto. En Medios sin fin. Notas sobre la política. Valencia, Pre-Textos.

»--------. (2016). Qué es un dispositivo. Buenos Aires, Adriana Hidalgo.

" Barthes, R. (1986). La escritura de lo visible. En Lo obvio y lo obtuso. Buenos Aires, Paidós.

" Montaldo, G. (2016). Museo del consumo. Archivo de la cultura de masas en Argentina. Buenos Aires, Fondo de Cultura Económica.

»Pavis, P. (2008). Diccionario del teatro. Dramaturgia, estética, semiología. Barcelona, Paidós.

»Porrúa, Ana, (2011), Caligrafía tonal. Ensayos sobre poesía. Buenos Aires, Editorial Entropía.

Fuentes

"Comoedia (1926-1931)

»De la Torre, R. (1928). “Intérpretes poéticos”. Comoedia, №37, 11 de mayo.

》-------. (1928a). Comoedia, $\mathrm{N}^{\circ} 41,1$ de septiembre.

»D’Artagnan. (1930). La verdad en marcha. El „“arte” de la Singermann juzgado por un profesor de literatura. Comoedia, $\mathrm{N}^{\circ} 57,1$ de enero.

» Martini, A. (1927). Los falsos apóstoles del arte lírico. Comoedia, № 21, 16 de marzo.

»Solari, F. (1927). “Intérpretes poéticos”. Comoedia, N²0, 16 de febrero.

»------. (1927). Comoedia, $N^{\circ} 21,16$ de marzo.

”Segovia, G. (1928). “¿Sirve la declamación para el teatro?”. Comoedia, № 39, 1ํㅡㄴ de julio.

»Villa, Alemany, J. L. (s/f). El Universo Poético. Poemas coleccionados por Alemany Villa. Buenos Aires, Casa Editora A. y G. Casellas.

»-------. (1927). El arte de interpretar las poesías. Comoedia, № 29, 1ํ de septiembre.

"--------. (1928). Intérpretes poéticos. Dos palabras. Comoedia, № 34, 11 de febrero.

$»------$. (1928). El arte y la cursilería. Comoedia, $\mathrm{N}^{\circ} 44,1^{\circ}$ de diciembre.

»-------. (1929). En la Escuela Argentina de Arte Universal. Cinco minutos con Alemany Villa. Comoedia, $N^{\circ} 51,1^{\circ}$ de julio. 
Anexo | "Por el mundo de la declamación", Comoedia, $\mathbf{N}^{\circ} 29,1^{\circ}$ de septiembre de 1927 , p. 40.

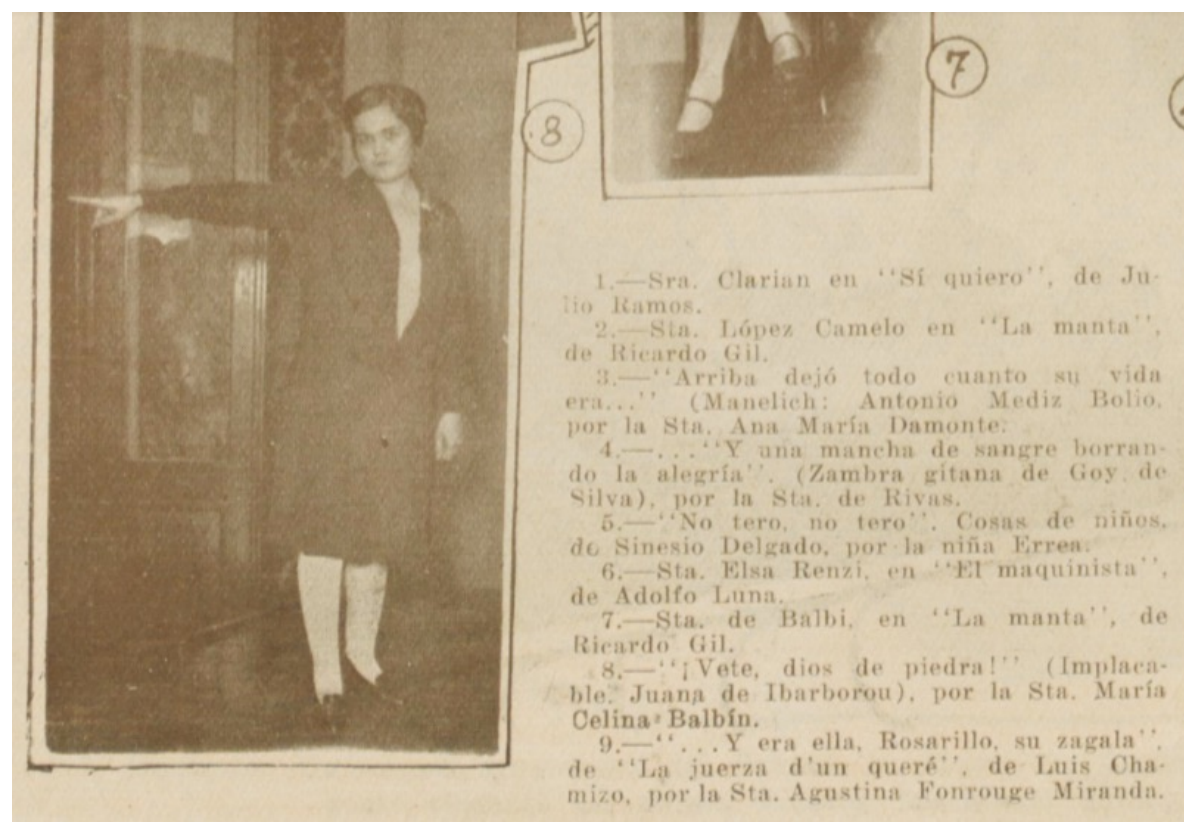

Figura 1.

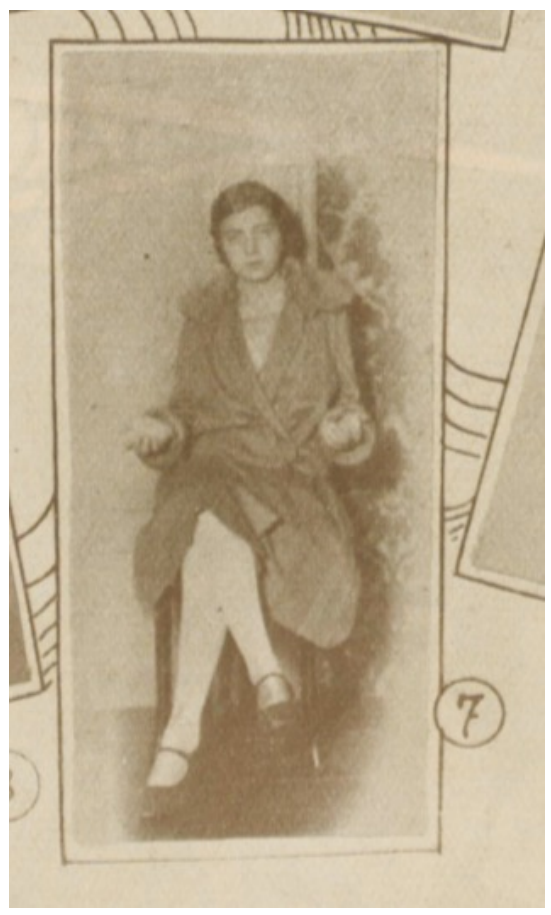

Figura 2. 
